\title{
SOME CHALLENGES ON THE BRAZILIAN RIGHT TO BE FORGOTTEN IN THE DIGITAL ERA
}

\author{
Francisco Nelson de Alencar $\mathrm{Jr}^{1 *}$, Luciana Helena Gonçalves. ${ }^{2}$
}

*Corresponding Author: -

\begin{abstract}
: -
This paper is about the right to be forgotten in the digital age. It aims to present some observations on the right to be forgotten in the digital era, in other words, a right of a person to delist an URL - Uniform Resource Locator - which causes him/her prejudice from the index of search engines, for instance, Google. We believe that the right to privacy has a new calling in the digital era, and, here, especially before search engines. In this way, the right to be forgotten in the digital era can represent an expansion of the protection of the right to privacy. As we will discuss, we believe that observations and the experience of the United States, for example, through the protection of the freedom of expression, and the combat of bad speech with more speech can help the Brazilian legal system to consider a practical way of protection of the privacy sphere on the internet.
\end{abstract}

Keywords: right to privacy; right to be forgotten; search engine; freedom of expression; access to information; Brazilian legal system. 


\section{INTRODUCTION}

This paper is about the right to be forgotten in the digital age. It aims to present some observations on the right to be forgotten in the digital era, in other words, a right of a person to delist a URL - Uniform Resource Locator (URL), which causes him/her prejudice from the index of search engines, for instance, Google.

When we are focusing on its search application, it can be noticed that this Google ${ }^{\text {ee }}$ function is based on helping information to be found. Google is a content provider which makes accessible data created or developed on the web by the information providers.

Information providers produce the information disclosed on the internet and web content can also be produced by internet users. In this paper we want to point out that Google makes the prejudicial information evident, something new about how information is reached on the web.

We also have to clarify some technical terms to understand the problem in the present case. One of them is that when you are searching for information through a search engine, you are not searching on the internet or on the web, in a way that we cannot request to "remove" the prejudicial information from there.

Instead, we are looking at that Google's search index, an index which is made by Google's algorithms through automated mechanisms of search engines, by extracting web content according to its relevance, among others criteria.

In this manner, when we talk about a search index it can be noticed that it is created through the extraction of web content, but not involving the internet as a whole. That is because, according to Leonardi (2005,p.10), the internet is the whole apparatus which enables data traffic, including, among others, the world wide web (www) and the electronic mail (the email). Therefore, the web is the audiovisual representation of a web site, and it is one of the possible applications which is made accessible through the internet.

Also, we have to point that in Brazil we do have another basis to found the right to be forgotten protection. This right which has been known as a right to be forgotten especially in Europe has a ground of legal protection both in this last continent and in U.S. regarding to be considered as involving a matter of personal data protection. Personal data can be indexed and listed by a search engine, for example, and concern and be prejudicial to a natural person.

What happens in Brazil is that the right to be forgotten which is understood as this right to delist before Google can be thought as an extension of the right to personality. This right to personality is foreseen in our Constitution (1988) and Civil Code (2002), for instance, and we understand that this right can be interpreted widely,

<http://convergenciadigital.uol.com.br/cgi/cgilua.exe/sys/start.htm?infoid=35154\&sid=4\#.U7N9vvldV05 >. Access on $14 / 03 / 2015$.

including the possibility of protection of all aspects which involve processes of life of a natural person.

In other words, in Brazil, we may have the protection of a person in his/her private life as grounded, since, on the right to personality, when it involves from his/her choices to marry, for example, to when it would involve his/her digital context of expression herself/himself on the internet.

This construction of the protection of a right to personality shows us that we have to think about different kinds of autonomies which are parts of our lives in society, for example: our self-determination, self-conservation and selfexposition.

We believe that the right to privacy has a new calling in the digital era, and to this paper, especially before search engines. In this way, the right to be forgotten in the digital era could represent an expansion of the protection of the right to privacy. According to our study, the right to personality, here applied specifically through the right to privacy includes the right to be forgotten before search engines.

\section{The right to be forgotten in the digital era in Brazil and in U.S.}

The North American legal system foresees the section 230 of the Communications Decency Act (CDA) which represents that there would not exista way toaddressCourts torequest the removal of information before a search engine.

The CDA"s section 230 provides the "PROTECTION FOR "GOOD SAMARITAN" BLOCKING AND SCREENING OF OFFENSIVE MATERIAL", defining the treatment of publisher or speaker, when "No provider or user of an interactive computer service shall be treated as the publisher or speaker of any information provided by another information content provider".

What is interesting is that despite of the existence of this legal immunity United States is a good example for the idea and practice of combating "bad speech with more speech".

One example is the existence of a market regulation in which in U.S. there is a way of business to contract the service of a reputation defender.

The service of a reputation defender functions as it describes itself by "pushing down unwanted results and replace them with items that better reflect who you are"4.

Another feature of the North American experience on this topic regards to its first amendment and its precaution with what is considered by some "vague terms", as those proposed by the European decision on the right to be forgotten.

The European Court of Justice has recognized the right to be forgotten in the digital era in 2014 by deciding that the inclusion in the list of results displayed following a search made on the basis of someone $\mathrm{s}$ name, indicating URLS to web pages published lawfully by third parties and containing true information related to someone personally is, at this point in time, incompatible with the European Directive on the protection of personal data (95/46/CE).

This decision was based on the conclusion which was justified "because that information appears, having regard to all the circumstances of the case, to be inadequate, irrelevant or no longer relevant, or excessive in relation to the purposes 
of the processing at issue carried out by the operator of the search engine. Therefore, the information and links concerned in the list of results must be erased".

This discussion is relevant in Brazil because what is happening here is the opposite. According to Marcel Leonardi (2008, p. 391), we do have the possibility to go to Court to request a content removal before a search engine, for instance. This happens, because of our Brazilian Civil Procedure Code (2015) which establishes the concession of court orders, by foreseeing that in order to put the fulfillment of this obligation into effect, the judge can order, among others measures, "the removal of people or things".

In this way, what is happening in Brazil is that Brazilians are going to Court in order to request no longer be have his/her name linked by a prejudicial information, and which, therefore, constitutes a result displayed following a search made on the basis of his/her name, which could involve, for instance, a reputational damage.

It is noticed that this understanding enables the data subject to address himself/herself to search engines in order to prevent indexing of the information related to him/her personally.

Hence, even if this information is lawfully published on third partiese web pages, Brazilians are able juridically to request the delisting, and without addressing in advance or simultaneously to the owner of the web page on which that information is located.

Currently, with the Brazilian Internet Law in force (2014), we also have another legal ground to go to Court and request the delisting of an URL before a search engine, which is an application provider, but the difference is that, in this case, a search engine will only be held responsible for the omission of not removing if it disobeys the court order. Before this Law, we had the possibility of a search engine to be held responsible after disobeying a simple notification of the user on the request of content removal.

Returning to the U.S. example, a case involving the interpretation of the section 230 of the DCA and a request of removal of content before a search engine is the Parker v. Google decision (2006).

The interesting about this case is that the plaintiff (Parker) has tried to hold Google liable for several claims, and each of these claims is based on separate conduct.

Three of these claims were based on the following: 1. Parker alleges that Google is liable for defamation because it archived defamatory messages posted by USENET users and because of defamatory statements located on a website Parker calls the "RayFAQ website," which was in Google "s cache. 2. Parker alleges that Google is liable for invasion of privacy because the act of Google users putting in a search query of his name leads Google to produce a list of websites in which his name appears, thus creating what he calls "an unauthorized biography of Plaintiff that is an invasion of his right to privacy." 3. Finally, Parker alleges that Google is liable for negligence for continuing to archive the "RayFAQ website" after being put on notice that it contained defamatory and threatening messages.

The judge Surrick, from the United States District Court for the Eastern District of Pennsylvania has decided in favor of Google, by concluding, among other considerations, the following about the DCA ${ }^{\text {ee }}$ section 230:

The intent of this provision is to “,preclude courts from entertaining claims that would place a computer service provider in a publisher's role. "e" Green v. Am. Online (AOL), 318 F.3d 465, 471 (3d Cir. 2003) (quoting Zeran v. Am.

Online, Inc., 129 F.3d 327, 330 (4th Cir. 1997)). Through $§ 230$, "Congress granted most Internet services immunity from liability for publishing false or defamatory material so long as the information was provided by another party. As a result, Internet publishers are treated differently from corresponding publishers in print, television and radio." (GORDON ROY PARKER v. GOOGLE, INC. CIVIL ACTION NO.04-CV-3918. MARCH 10, 2006).

Finally, we bring an observation about an interesting debate which happened in New York, promoted by the Intelligence ${ }^{2}$ Debate, on the following motion: "should the

U.S. adopt the ,right to be forgotten" online"?

The debaters arguing in favor of the motion are the director at the European Commission "es Justice Unit, Paul Nemitz and the University of Chicago Law professor Eric Posner. Opposing them, were the former director of Global Public Policy at Google Andrew McLaughlin and the Harvard Professor of Internet Law, Jonathan Zittrain.

The debate has discussed the possibility of giving North American citizens the right to be forgotten in the digital era, and, if so, if this would represent a win for privacy and human dignity or a blow to free speech and public information.

The audience was able to vote for or against the motion two times: before the debate and after the possibility of hearing the arguments of the debaters and the audience ees questions being answered.

Before the debate, the pool results were the following: $36 \%$ for the motion, $26 \%$ against it, and $38 \%$ undecided. After the debate, the pool results were $35 \%$ for the motion, $56 \%$ against it, and $9 \%$ undecided.

The results of this debate can show us two things. The first one is that the right to be forgotten - which is here understood as a component of the right to privacy - matters to the North Americans.

On the other hand, the debate has pointed to difficulties which would involve the realization of a feasible protection of online privacy in front of the relevance of the access to information and freedom of expression.

In this way, the debaters against the adoption of the right to be forgotten in U.S. won, because they show that intermediary solutions should be considered, in compensation of the idea of totally applying the right to be forgotten as proposed by the Court of Justice of the European Union in 2014.

What should be also considered is that American experiences can be an example of solutions if the right to be forgotten cannot be applied as it is was conceived by the European Court of Justice. 
So, according to our study, we cannot agree with the general statement in which there would not exist ideas to solve the privacy right protection issue in U.S., because, for instance, the freedom of expression would always win. What we have ascertained is that the American considerations are more skeptical in order to be more feasible to be applied.

\section{Conclusion}

The proposal of this paper was to consider a "Brazilian" right to be forgotten in the digital era and which could learn not only with the European experience towards the protection of the right to privacy, at is commonly studied in Brazil.

We have included the North American experience because it is being considering the right to online privacy through practical thoughts, by applying an idea of market regulation and the freedom of expression value.

In this way, the North American "e s example is interesting to be considered, even if Brazil tends to follow the European trend toward an increasingly protection of the right to privacy.

We believe that the right to privacy has a new calling before the digital era, and here especially before search engines. In this way, the right to be forgotten in the digital era could represent an expansion of the protection of the right to privacy.

<http://leginfo.legislature.ca.gov/faces/billNavClient.xhtml?bill_id=201320140SB568>. Access on: 19/05/2015.

As we could see, we believe that observations and experience of the United States, for example, through the protection of the freedom of expression, and the combat of bad speech with more speech can also help the Brazilian legal system to consider a practical way of protection of the privacy sphere on the internet.

By taking another example into account, we understand that more viable possibilities of realizing this right could be thought, in order regulate the right to be forgotten through an increasingly feasible manner.

\section{REFERENCES}

[1].BRAZIL. Superior Tribunal de Justiça. Recurso Especial no 1.316.921 - RJ (20110307909-6). Recorrente: Google Brasil Internet LTDA. Recorrida: Maria da Graça Xuxa Meneghel. Relatora: Min. Fátima Nancy Andrighi. 26/06/2012. Disponível em: <http://stj.jusbrasil.com.br/jurisprudencia/22026857/recurso-especial-resp1316921-rj2011-0307909-6-stj/inteiro-teor-22026859>. Acesso em 01 mar. 2014.

[2].LEONARDI, Marcel. Responsabilidade civil dos provedores de serviços de internet. São Paulo: Juarez de Oliveira, 2005. v. 1.

[3].LEONARDI, Marcel. Controle de Conteúdos na Internet: filtros, censura, bloqueio e tutela.In: Direito e Internet: aspectos jurídicos relevantes. Vol II. DE LUCCA, Newton; SALOMÃO FILHO, Adalberto. (Coord). 2008. Editora Quartier Latin.

[4].GORDON ROY PARKER v. GOOGLE, INC. CIVIL ACTION NO.04-CV-3918. MARCH 10, 2006.R. Barclay Surrick, Judge. IN THE UNITED STATES DISTRICT COURT FOR THE EASTERN DISTRICT OF PENNSYLVANIA.Availableat:< https://www.eff.org/files/parker-V-google.pdf $>$. Access on: 19/05/2015. 